\title{
Epidemiological profile of octogenarian patients admitted to our intensive care unit (ICU) because of an acute coronary syndrome (ACS). is there an adequate resources management?
}

\author{
A Puerto-Morlán*, MA Estecha-Foncea, A Fernandez Poncel, P Nuevo-Ortega, L Ruiz-Del-Fresno, C Reina-Artacho
}

From ESICM LIVES 2015

Berlin, Germany. 3-7 October 2015

\section{Introduction}

During the last decades is becoming more frequent to admit patients older than 80 in the Intensive Care Unit (ICU). One of the most common reasons for admission of these patients is Acute Coronary Syndrome (ACS). We decide to study specifically this population, which has distinctive features but has not been fully studied because its advanced age has been an exclusion criteria in most clinical trials.

\section{Objectives}

To describe epidemiological features of patients older than 80 , admitted in a our ICU because of ACS. We analyzed mortality and functional capacity at six month time after the event.

\section{Methods \\ We carried out an observational study examining clini- cal records of all patients admitted in our Unit between June 1, 2013 and June 30, 2014, aged 80 or older. We collect information about basal physical and functional state, type of ACS, treatment applied and evolution. Patients or their contact relatives, were interviewed again 6 months after admission to know their vital and functional state, that was evaluated with Barthel Index (BI).}

\section{Results}

Fifty two patients were studied, 80,8\% (42 patients) were admitted because of ST Elevation ACS (STEACS), and the rest Non STE ACS (NSTE AVS). In STEACS patients reperfusion strategy was Primary Percutaneous Coronary Interventionism (PPCI) in $78,5 \%$ of cases, fibrinolysis $21,4 \%$. In patients with NSTEACS $80 \%$ were treated with PCI in $80 \%$, and surgically $10 \%$. In STEACS total delay between symptoms onset and PPCI was $4.6 \mathrm{~h}$ $+/-3.97 \mathrm{~h}$; in contrast with NSTEACS where this delay was $72 \mathrm{~h}+/-53 \mathrm{~h}$ (mean +/-SD). Global mortality rate was $21.5 \%$ (11 patients) in ICU, and $34.6 \%$ (18) at 6 months, among STEACS patients it was $40.4 \%$ (17) and in NSTEACS patients 10\% (1).

Regarding place of death, $61.1 \%$ die in ICU (11 out of 18 patients), $16.6 \%$ (3) in hospital out of ICU, and $22.2 \%$ (4) after discharge to home. Regarding 34 survivors, functional state at six month could be recovered in 28 , and $50 \%$ of them had a BI score $<90$ points (moderate, severe or total dependency), and $35.7 \%$ less than $60 \mathrm{BI}$ points indicating severe or total dependency 6 months after the admission.

\section{Conclusions}

Patients older than 80 , admitted in ICU because of STEACS have a high mortality rate, higher than expected from previous literature: in GRACE registry ([1]), global mortality was $9.3 \%$ for patients between 75 and 85 years old and $18.4 \%$ for those older than 85 . In addition, a high percentage of survivors remain with at least moderate dependency. And this in spite of an optimal treatment according to current clinical guidelines. It is necessary to design studies in this subgroup of patients, oriented not only to mortality but also to quality of life; to better identify in what patients this treatments are cost-efficient. 


\section{Reference}

1. Avezum A, Makdisse M, Spencer F, et al: Impact of age on management and outcome of acute coronary syndrome: observations from the Global Registry of Acute Coronary Events (GRACE). Am Heart J 2005, 149:67-73.

doi:10.1186/2197-425X-3-S1-A756

Cite this article as: Puerto-Morlán et al:: Epidemiological profile of

octogenarian patients admitted to our intensive care unit (ICU) because

of an acute coronary syndrome (ACS). is there an adequate resources

management? Intensive Care Medicine Experimental 2015 3(Suppl 1):A756.

\section{Submit your manuscript to a SpringerOpen ${ }^{\mathcal{O}}$ journal and benefit from:}

- Convenient online submission

- Rigorous peer review

- Immediate publication on acceptance

- Open access: articles freely available online

- High visibility within the field

- Retaining the copyright to your article

Submit your next manuscript at $\gg$ springeropen.com 